\title{
DETERMINANTS OF THE CHOICE OF COMBINED MODES FOR FOREIGN MARKET ENTRY: THE CASE OF KOREAN FIRMS ENTERING INTO UZBEKISTAN
}

\author{
Wonchan Ra \\ Hankuk University of Foreign Studies, Republic of Korea
}

\begin{abstract}
The choice of an entry mode is one of the most critical decisions for firms expanding abroad. There are a variety of foreign market entry modes such as exporting, licensing, and foreign direct investment. While many firms use only one single mode, others frequently employ multiple different combined modes for a foreign entry simultaneously. Mode combination can be an effective way to achieve better performance in foreign operation because the different modes in a combination package complement each other. The topic of mode combination, however, has not yet been extensively studied theoretically and empirically. In this paper, we propose six hypotheses to examine factors affecting firms' choice between a single mode and a combined mode and test them on questionnaire survey data regarding Korean manufacturing firms' recent entry into Uzbekistan.
\end{abstract}

Keywords: entry modes, combined entry modes, Korea, Uzbekistan

DOI: http://dx.doi.org/10.15549/jeecar.v7i1.380

\section{INTRODUCTION}

Firms entering into a foreign market face a decision to choose an appropriate entry mode. There are various types of entry modes such as exporting, licensing, joint ventures (JVs) and wholly owned subsidiaries (WOSs). Each mode is associated with varying degrees of the resource commitment, control and risk involved in the mode (Hill, Hwang \& Kim, 1990; Contractor, 2001).

The extant literature on firms' entry mode choice focuses on the choice of a single one among various modes, but in the real world, multiple different modes for an entry are simultaneously employed in many cases (Benito
\& Welch, 1994; Benito, Petersen \& Welch, 2011). Individual single modes can be mixed and combined like one mode in a packaged form. For example, a foreign direct investment can be combined with exporting, licensing or both exporting and licensing. In other words, the firm may have equity ownership in its subsidiary established by making an FDI and at the same time, form an intra-firm trade and/or intra-firm licensing relationship with the subsidiary (Contractor, 2001; Hashai, Asmussen, Benito \& Petersen, 2010; Benito, et al., 2011). A combined mode enables the firm to enjoy larger financial and strategic benefits in a synergistic way. Nonetheless, mode combination has not been sufficiently examined in the literature on foreign 
market entry modes (Benito, et al., 2011).

In this paper, we will examine factors affecting firms' choice of combined modes for foreign market entry. In doing so, we will establish hypotheses regarding the factors deemed to influence firms' choice between a single mode and a combined mode, focusing primarily on basic forms of combined modes such modes as FDI combined with exporting, FDI with licensing, and FDI with both exporting and licensing (Contractor, 2001). Then, we will empirically test the hypotheses with questionnaire survey data on Korean firms in Uzbekistan. Central Asian countries have attracted more inward FDI from Korea since their independence from the former Soviet Union in 1991 and among them, Uzbekistan has emerged as one of the major FDI target countries. Between 1992 and now, 340 Korean companies actively invested in Uzbekistan, their FDI totaling $\$ 723$ million, and over $60 \%$ of the amount concentrating in manufacturing. Major large Korean firms that have recently entered Uzbekistan include Samsung Electronics, LG Electronics and POSCO. The Korean FDI has contributed much to the Uzbekistan economy, strengthening the economic relationship between two countries (UzReport, 1999-2015). However, there has been little empirical research on the behavior of Korean firms entering into Uzbekistan up to now, motivating us to examine this topic.

Through this paper, we hope to contribute to research on foreign entry modes by looking at mode combination which has not given enough attention in the existing literature, and to draw significant implications for governmental policy on inward and outward FDI at the national level.

The remaining part of the paper is organized as follows. Section 2 provides an overview of the properties of single-entry modes and theoretical aspects of mode combination. Then Section 3 presents six hypotheses regarding the determinants of firms' choice between a single and a combined mode. Section 4 provides data, variables, measurements, test results and discussion. The final section introduces a summary and limitations of the study, the direction for further research, and managerial and policy implications.

\section{THEORETICAL BACKGROUND}

The choice of foreign market entry modes by firms entering into a foreign market has been one of the most studied topics in international business (IB) research for decades (Root, 1987; Hennart \& Slagen, 2015; Schellenberg, Harker \& Jafari, 2018). A foreign entry mode is a mode of organizing the firm's foreign business activities (Hill, et al., 1990) or an institutional arrangement that allows the firm to bring products to the foreign market (Pehrsson, 2008).

Entry modes can be broadly divided into nonequity and equity-based modes (Pan \& Tse, 2000). Non-equity-based modes include indirect and direct exporting, and contractual modes such as licensing, franchising, turnkey projects, R\&D contracts and co-marketing. JVs and WOSs are the main forms of equity-based modes and both are established by the firms' foreign direct investment (FDI). Entry modes considerably differ in regard to the involved competitive advantage, resource commitment, control, risk exposure, and profit distribution between partners. In general, equity-based modes entail larger resource commitment and higher levels of control over the foreign operation by the investing firm, while non-equity modes involve less resource commitment and lower levels of control (Contractor, 2001; Hill, et al., 1990).

The extant literature deals with a broad range of entry mode issues including determinants of mode choice, decision making process and performance, etc. The major findings of the literature that are more relevant to the objective of this study are as follows. Shen, Puig and Paul (2017) stressed the interaction effects on mode choice between cultural distance, institutional uncertainties and experience, rather than on the linear relationship between any two of these. Wulff (2016) also found that the effects of some factors on mode choice such as asset specificity frequently used in the existing studies are not consistent, and the effects can vary depending on measurement. Shellenberg, Harker and Jafari (2018) found the relative lack of adequate interest in smaller firms, decision making processes within firms and integrated perspectives. In tackling the entry mode issue, some authors take a narrower scope focusing on SMEs (Lauf \& Schwens, 2014; Bruneel \& De Cock, 2016), MNEs from emerging markets (Surdu, 
Mellahi \& Glaister, 2018) and the situation under behavioral uncertainty (Ahsan \& Musteen, 2011).

After fully considering the advantages and disadvantages of each mode, firms may make the choice of one among various modes in entering into a foreign market. Alternatively, firms can mix different single-entry modes for a foreign entry (Contractor, 2001; Hashai, et al. 2010; Benito, et al., 2011). For example, FDI is simultaneously used together with exporting, licensing, or both exporting and licensing. Such combined modes are also called mixed modes and mode packages (Benito, et al., 2011). From this perspective, foreign entry modes can be broadly classified into single modes and combined modes.

The rationale of mode combination varies according to the situation. Licensing can be combined with a JV to control the flow of knowledge transfer and to generate additional revenue. Also, exporting can be used with a JV to secure stable cash flows in addition to supplying quality input to the JV. In such combinations, the JV can play a role as the primary mode in the package, with licensing and exporting playing supporting roles (Contractor \& Ra, 2000).

Among various single-entry modes, exporting, licensing and two FDI modes, JVs and WOSs, are most common (Agawal \& Ramaswami, 1992). Let us consider one general case where the foreign firm establishes a JV in the local market, concludes a licensing contract for the knowledge and technology transfer with the JV, and forms a trade relationship whereby the firm exports critical parts and components to the JV.

Such mode combination may have the following economic, strategic, negotiation and behavioral rationales. First, on the economic aspect, the dividends from the ownership participation in the JV are its share in the JV distributable profit that, without expiration, can be very large in absolute terms. Royalties are paid according to the JV sales, regardless of the size of its profit, and the margin on exports to the JV can be a less cyclical revenue source (Contractor, 2001).

Second, from a strategic perspective, the licensing mode added to the JV can provide the foreign firm with higher control over the local operation and legal security of intellectual property rights in the local market (Contractor \&
Ra, 2000), alleviating the foreign firm's concerns over knowledge leakage or rent misappropriation.

Third, entry mode negotiations in IB between partners entail a very complex process (Yan \& Gray, 1994). Since positive revenue streams and strategic benefit to one partner can be the opposite to the other, negotiating the deal more flexibly over multiple modes rather than over one mode can raise the possibility that it will turn out to be more successful to both the foreign firm and local partner.

Fourth, some scholars (e.g., Benito, et al., 2011) propose a behavioral explanation: Managers make decisions on entry modes with limited information and under cognitive imperfection, and thus often choose compromising combined modes, albeit they are aware that in fact this may be suboptimal. Viewed from this perspective, any combined modes can be considered temporary and be changed into a different single mode or combined modes with different elements after the entry.

In sum, mode combination can provide the foreign firm with a larger sum of more stable revenue and a higher level of control over the foreign operation, and the higher chance of the success of the entry mode negotiation with the local partners, although it may be the suboptimal result of the manager's bounded rationality.

\section{HYPOTHESES}

Then, what determines the firm's choice between a single mode and a combined mode for a foreign market entry? To answer this question, we surveyed the existing literature on the traditional choice of one among many single modes since little empirical research on the topic of our study has been conducted yet. In deciding on single entry modes, the chosen mode for a foreign entry may be the result of the interplay of four variables, i.e., risk, return, resource commitment and control (Agarwal \& Rawaswami, 1992). Considering the general rationale for firms' foreign market entry from this perspective, we apply the same traditional logic for single mode choice to the issue of the choice of combined modes.

Surveying the entry mode literature (e.g., Hill, et al., 1990; Agarwal \& Rawaswami, 1992) and 
following Canabal and White (2008), we extracted six external and internal variables deemed to explain firms' choice between a single and a combined mode, such as firm size, international involvement, product differentiation, perceived investment risk, perceived contractual risk, and the amount of the expected cost of controlling the foreign operation.

First, the size of a firm often constrains the financial and managerial resources that it can use. Larger firms usually have more resources to foreign entry (Ang, Benischke \& Doh, 2015) because large firms tend to enjoy the benefits from their scale, scope and tangible and intangible assets.

The relationship between firm size and the use of equity-based entry modes has been widely investigated and firm size is considered one of the important determinants of entry mode choice (Agarwal \& Ramaswami, 1992; Brouthers, 2002; Anderson \& Gatignon, 1986). In general, larger firms have a higher propensity to expand abroad and if they do, prefer equity forms to nonequity modes more than smaller firms do.

In the context of the choice between a single and a combined mode, in general, the process of formulating, negotiating and managing combined modes is much more complex and time consuming, compared to single modes (Contractor, 2001; Contractor \& Ra, 2000). Thus, it can be inferred that a combined entry mode requires more resources for such process. Larger firms that have more resources to commit are more likely to be in a position to employ a combined mode than smaller ones do. Hence, ceteris paribus,

Hypothesis 1: Larger firms are more likely to choose a combined entry mode over a singleentry mode.

A firm's previous and current involvement in international business or foreign activities may affect its future internationalization behavior, which has been well documented in the extant literature (Canabal \& White, 2008; Wulff, 2016; Schellenberg, et al., 2018). The accumulated international involvement can help the firm effectively reduce the environmental uncertainties and increase the awareness of opportunities in foreign markets. The firm can utilize such experience in selecting an appropriate foreign entry mode (Ahsan \& Musteen, 2011; Herrmann \& Datta, 2006).

The relationship between international involvement and entry mode choice is better elaborated in the international experience literature. Firms with more experience tend to prefer a higher control mode while firms with less experience prefer a lower control mode (Agarwal \& Ramaswami, 1992). Caves and Mehra (1986) also found that international experience is significantly correlated with the choice of acquisition over greenfield investment. Furthermore, Kogut and Singh (1988) showed that more internationally experienced firms are less likely to share the risks and management responsibility through a JV and more likely to prefer acquisition.

In the dynamic sense, Johnson and Vahlne (1977), one of the earliest studies on entry modes, showed that in expanding business into new markets, firms tend to change their entry modes from a lower commitment mode such as exporting to a higher commitment one such as production unit as they gain more experience in the market.

Combined modes for foreign entry are more complex to formulate and implement in operation than single ones (Contractor \& Ra, 2000) and thus previous and current international involvement may help the firm effectively deal with the difficulties with combined modes. Therefore, firms with more international involvement are more likely to choose a combined mode than those with less international experience. Therefore, ceteris paribus,

Hypothesis 2: Firms with more international involvement are more likely to choose a combined entry mode over a single-entry mode.

Since Hymer (1960), firms' monopolistic advantage has been emphasized as a tool utilized to effectively overcome the cost or liabilities of foreignness in foreign markets (Kostova \& Zaheer, 1999). Many authors frequently cited the R\&D intensity and advertising intensity of the firm as sources of monopolistic advantage (e.g., Lall, 
1980; Canabal \& White, 2008), proposing that a stronger monopolistic advantage is directly related to the preference for higher control modes such as FDI to arm's length transactions such as licensing. The monopolistic or competitive advantage of the firm can be developed by long-term investment, reflecting the level of differentiation of the product that the firm serves to the market (Porter, 1985).

Firms entering into a foreign market with more differentiated products will attempt to generate profit from the use of more diverse and stable entry modes in order to recoup the higher investment cost and to maintain their competitive position in the market. Firms offering more differentiated products will have more options to be equipped with a larger number of entry modes based on the competitiveness and knowledge components of the products, allowing them to use a combined mode. Accordingly, ceteris paribus,

Hypothesis 3: Firms with more differentiated products are more likely to choose a combined entry mode over a single-entry mode.

The investment risk in a host country reflects the uncertainty over the continuation of present economic and political conditions and overall policies which are critical to the survival and profitability of a firm's operations in that country. According to Root (1987), there are four types of investment risk that have a significant impact on firms' foreign entry decision: Political risk (e.g., instability of political system), ownership control risk (e.g., expropriation, nationalization), operation risk (e.g., price control, local content requirements), and transfer risk (e.g., currency inconvertibility risk, remittance control). When the investment risks are perceived to be high, the firm attempts to limit its exposure to them, e.g., by reducing upfront resource commitment (Hill, et al., 1990; Ahsan \& Musteen, 2011). By doing so, the firm can maintain higher flexibility for future exit (Gatignon \& Anderson, 1988), thus creating an option to make more commitment in the future (Ahsan \& Musteen, 2011).

In selecting single foreign entry modes, higher perceived investment risk such as political risk (e.g., the instability of political system), ownership control risk (e.g., expropriation), operation risk (e.g., local content requirements), and transfer risk (e.g., remittance control), may discourage the use of higher commitment modes and encourage the choice of lower commitment modes (Agarwal \& Ramaswami, 1992; Kim \& Hwang, 1992) in order to maximize risk adjusted profit.

In the context of the choice between a single and a combined mode, one way to more effectively cope with such investment risk will be to use mode combination by employing multiple modes at the same time. Each of the component modes included in the combination package differs in their property and work together, complementing each other. For example, the revenue from intra-firm trade and intra-firm licensing can compensate for the loss from operational and transfer risks since trade margins and licensing royalties are legally bound under contractual arrangements. With the elements combined inside, a combination package can enable the firm faced with investment risks to have more stable revenue source and more flexibility in operation. Licensing royalties and margins on the intra-firm trade can complement dividends and vice versa. Hence, ceteris paribus,

Hypothesis 4: When the investment risk is perceived to be higher, firms are more likely to choose a combined entry mode over a singleentry mode.

The resource-based view (RBV) of the firm avers that a firm's competitive advantage depends on its tangible assets and knowledge (Barney, 1991). The firm's knowledge such as intellectual properties, knowhow and organizational capability can be also a major source of competitive advantage in a foreign market. When such knowledge is transferred abroad, the firm runs the risk of 'misappropriation,' the partners misusing and disseminating it (Hill, et al., 1990) and free-riders' degrading its value in the case of brand in the local market (Anderson \& Gatignon, 1986). If this is the case, the firm cannot fully capture the revenue for knowledge utilization from the foreign entry. All this may raise the possibility that local partners may illegally capture the substantial portion of the revenue from the utilization of knowledge, which is called the 'appropriability' problem (Teece, 1986) causing 
contractual risk.

Transaction cost theory (TCT) has been extensively used to explain entry modes, its main tenet being that firms can select a governance mode which minimizes the transaction cost when they organize economic activities (Coase, 1937; Williamson, 1979). From the TCT perspective, the measure for contractual risk is to be equipped with a governance mode that will control the local partners' misbehavior (Canabal \& White, 2008). The firm, for instance, can employ a high control mode such as exporting and a WOS for protecting its knowledge and competitive advantage (Agarwal \& Rawaswami, 1992).

When the contractual risk in the local market is perceived to be high, in the context of the choice between a single mode and a combined mode, the latter can provide the firm with a higher capability to cope with such risk than the former. For example, a licensing agreement combined with a JV can more effectively protect the transferred knowledge through by the legal enforcement (Contractor \& Ra, 2000). Hence, ceteris paribus,

Hypothesis 5: When the contractual risk is perceived to be higher, firms are more likely to choose a combined entry mode of entry over a single-entry mode.

TCT, as discussed above, basically takes a comparative approach to the issue of the choice of an organization mode since its logic is based on the comparison of the relative costs of alternative modes. In that each mode differs in the way of organizing activities, a certain mode can be more efficient in organizing a particular type of transaction (Hennart, 1989). Accordingly, the existing entry mode studies based on TCT, e.g., Anderson and Gatignon (1986) also take a comparative approach.

In evaluating alternative entry modes, however, firms also consider the absolute amount of the expected cost of controlling the foreign operation incurred by the chosen mode. The ability of the firm to bear the expected control cost as well as the cost differences among modes will affect its decision making on entry modes.

The amount of the resource commitment needed for a single mode is less than that for a combined mode since the latter involves a larger number of different modes. When the cost of controlling the foreign operation is expected to be high, the firm will try to make less resource commitment, preferring a single mode to a combined mode. Hence, ceteris paribus,

Hypothesis 6: When the amount of the control cost is expected to be large, firms are more likely to choose a single-entry mode over a combined entry mode.

\section{METHODOLOGY}

Sample. The data for this study were collected through a survey of Korean firms that had entered Uzbekistan. They were on the list published by Korea Trade-Investment Promotion Agency sponsored by the Korean government. We first targeted 300 firms in manufacturing of a total of the 363 firms in all industries and finally we could interview 103 firms after contact.

We created an English-language questionnaire that contained questions asking the level of the sample firms compared to the industry average on a 7-point Likert scale where $1=$ lowest and 7 = highest. After a pilot-test for a few firms, the English-language questionnaire was translated into Russian and the survey was conducted between April and May 2015.

To illustrate some characteristics of the sample, of the 103 firms, 30 used single modes (29.1\%) and 73 used combined modes (70.9\%). As to firm size, 46 (67.0\%) were large firms (44.7\%), 17 medium ones (16.5\%) and 40 small ones (38.8\%), and $69(67.0 \%)$ entered into Uzbekistan before 2010 while 32 (35.9\%) after 2011 (two were unknown).

To avoid the common method bias (CMB) problem, we first designed the questionnaire very carefully to minimize possible CMB: No questions were included which required respondents to judge situations as right or wrong, and from the flow of the survey questions, respondents could not hypothesize any associations between dependent and independent variables. Moreover, the dependent variable in this study is a simplistic objective dyadic one that is easily observable. Thus, we believe that there is little possibility that such sources of any artifactual covariance and CMB 
problems in this study might occur.

Model. Since the dependent variable in this study is dichotomous, a single mode or combined mode, an appropriate statistical estimation technique is binary logistic regression. The maximum likelihood method is used for estimation. This technique is oriented to estimating the probability of an event occurring and has been frequently utilized in studies (Canabal \& White, 2008). The logistic regression model is as follows. From the logit function $\operatorname{logit}(P)=\ln (P /(1-P)$,

$$
P\left(Y_{i}\right)=1 /\left(1+\exp \left(B_{0}+B_{1} X_{1}+B_{2} X_{2}+\ldots \ldots+B_{6} X_{6}+\varepsilon_{i}\right)\right)
$$

where:

$Y=0$ single mode and $Y=1$ combined mode $Y_{i}$ is the dependent variable, defined by a dummy variable, either one or zero. $X_{\mathrm{i}}^{\prime} \mathrm{s}$ are the independent variables and $B_{0}$ is the intercept parameter. $B_{i}$ 's are the regression coefficients. A positive sign for the coefficient means that the variable increases the probability of the event occurring, and a negative sign signifies the opposite. The maximum likelihood estimates of the parameters were obtained by employing SPSS.

Measurement. The dependent variable is a mode of foreign entry: One is a single mode that is one of exporting, contractual agreements, i.e., licensing and franchising, a JV or a WOS, and the other is a combined mode of a JV or WOS with one or more of other single modes.

Independent variables were measured as in Table 1 which shows that the Cronbach's $\alpha$ for each variable with multi-items, which ranges from 0.618 to 0.894 , is generally acceptable.

The Pearson correlation matrix of the independent and dependent variables is shown in Table 2. The pairwise correlations between independent variables do not present any serious multicollinearity problems as none of the variables have correlation coefficients above 0.50 and a value of variance inflation factor (VIF) below 10 (Allison, 1999).

Table 1. Measures and the reliability of the variables

\begin{tabular}{|c|c|c|c|}
\hline Variables & Description & References & Cronbach's $\alpha$ \\
\hline $\begin{array}{l}\text { Mode: } \\
\text { single; } \\
\text { combined }\end{array}$ & $\begin{array}{l}\text { One of exporting, licensing, } \\
\text { franchising, JV, WOS; JV or WOS } \\
\text { with exporting and/or licensing }\end{array}$ & & \\
\hline Firm size & $\begin{array}{l}\text { Number of total employees } \\
\text { Production capacity } \\
\text { Total sales }\end{array}$ & $\begin{array}{l}\text { Herrmann \& Datta (2006) } \\
\text { Ang, et al. (2015) } \\
\text { Pehrsson (2008) }\end{array}$ & 0.894 \\
\hline $\begin{array}{l}\text { International } \\
\text { involvement }\end{array}$ & $\begin{array}{l}\text { Foreign sales/total sales } \\
\text { Foreign profit/total profit }\end{array}$ & $\begin{array}{l}\text { Geringer, Beamish \& } \\
\text { daCosta (1989) }\end{array}$ & 0.868 \\
\hline $\begin{array}{l}\text { Product } \\
\text { differentiation }\end{array}$ & $\begin{array}{l}\text { New products } \\
\text { High quality products }\end{array}$ & Morrison \& Roth (1992) & 0.847 \\
\hline $\begin{array}{l}\text { Perceived } \\
\text { investment risk }\end{array}$ & $\begin{array}{l}\text { Perceived political risk } \\
\text { Policy risk }\end{array}$ & Buckley (1988) & 0.788 \\
\hline $\begin{array}{l}\text { Perceived } \\
\text { contractual risk }\end{array}$ & $\begin{array}{l}\text { Risk of IP deterioration } \\
\text { Risk of IP dissipation }\end{array}$ & $\begin{array}{l}\text { Anderson \& Gatignon } \\
\text { (1986) }\end{array}$ & 0.876 \\
\hline $\begin{array}{l}\text { Expected } \\
\text { control cost }\end{array}$ & $\begin{array}{l}\text { Cost of implementing transaction } \\
\text { Cost of network establishment } \\
\text { Cost of acquiring and using info }\end{array}$ & & 0.618 \\
\hline
\end{tabular}


Table 2. Correlation matrix

\begin{tabular}{|l|r|r|r|r|r|r|r|}
\hline \multicolumn{1}{|c|}{ Variables } & $\mathbf{0}$ & $\mathbf{1}$ & $\mathbf{2}$ & $\mathbf{3}$ & $\mathbf{4}$ & $\mathbf{5}$ & $\mathbf{6}$ \\
\hline 0. Entry mode & 1.000 & & & & & & \\
\hline 1. Firm size & $0.506^{* *}$ & 1.000 & & & & & \\
\hline 2. International & 0.057 & 0.145 & 1.000 & & & & \\
\hline 3. Differentiation & 0.037 & $0.349^{*}$ & -0.063 & 1.000 & & & \\
\hline 4. Investment risk & -0.088 & $0.221^{*}$ & 0.071 & -0.051 & 1.000 & & \\
\hline 5. Contractual risk & 0.074 & -0.079 & 0.165 & 0.005 & $0.292^{* *}$ & 1.000 & \\
\hline 6. Control cost & -0.128 & -0.047 & 0.082 & -0.143 & 0.088 & 0.254 & 1.000 \\
\hline Average & 0.706 & 4.670 & 4.887 & 4.848 & 2.029 & 2.167 & 3.895 \\
\hline Standard deviation & 0.458 & 1.267 & 1.389 & 1.226 & 1.064 & 1.172 & 0.867 \\
\hline \multicolumn{1}{|c|}{ VIF } & & 1.249 & 1.079 & 1.148 & 1.191 & 1.095 & 1.186 \\
\hline
\end{tabular}

Notes $^{* *}$ : Significant at the $1 \%$ level (2-tailed); *: Significant at the $5 \%$ level (2-tailed).

Test results and discussion. The test results from the logistic regression are displayed in Table 3. Regarding model fit, the $\chi^{2}$ statistic (39.881, $\mathrm{df}=6, p<0.000$ ) allows the rejection of the null hypothesis that all the estimated coefficients are zero. The -2 log likelihood statistic turned out 102.431, and the Cox \& Snell $\mathrm{R}^{2}(0.321)$ and the Nagelkerke $\mathrm{R}^{2}(0.429)$ do not reach a maximum value of 1 . All this evidence indicates that the model has a good fit. Thus, we can proceed to check the coefficient estimates for individual independent variables.

For the first variable, there is a relatively strong support for Hypothesis $1\left(B_{1}=+1.399, p<0.000\right)$. This result confirms that larger firms with more resources prefer a combined mode with a higher level of resource commitment, echoing many strategy scholars' arguments (Canabal \& White, 2008).

The international involvement variable turned out to be insignificant, rejecting Hypothesis 2 . This is contrary to the implications from the well documented findings (e.g., Johanson \& Vahlne, 1977) that as the firm's internationalization experience is accumulated, a higher level of different entry modes are likely to be used. Our result may be due to the fact that the determinants of the choice of one among discrete single-entry modes are different from those for the choice between a single and a combined entry mode, which may require different types or levels of knowledge.

Table 3. Estimated coefficients

\begin{tabular}{|l|r|r|r|r|r|r|}
\hline \multicolumn{1}{|c|}{ Determinants } & \multicolumn{1}{c|}{ B } & \multicolumn{1}{c|}{ S.E. } & \multicolumn{1}{c|}{ Wald } & \multicolumn{1}{c|}{ df } & \multicolumn{1}{c|}{ Sig. } & \multicolumn{1}{c|}{$\operatorname{Exp(B)}$} \\
\hline Firm size & 1.399 & 0.305 & 20.191 & 1 & $0.000^{* * *}$ & 4.049 \\
\hline $\begin{array}{l}\text { International } \\
\text { involvement }\end{array}$ & -0.598 & 0.664 & 0.524 & 1 & 0.368 & 0.550 \\
\hline Differentiation & -0.511 & 0.234 & 3.116 & 1 & $0.029^{* *}$ & 0.600 \\
\hline Investment risk & 0.075 & 0.862 & 2.195 & 1 & 0.930 & 1.078 \\
\hline Contractual risk & 0.479 & 0.240 & 9.042 & 1 & $0.046^{* *}$ & 1.615 \\
\hline Control cost & -0.613 & 0.324 & 5.685 & 1 & $0.058^{*}$ & 0.542 \\
\hline Constant & -2.008 & 1.727 & 4.961 & 1 & 0.245 & 0.134 \\
\hline
\end{tabular}

Note: Significant at the level ${ }^{* * *} \mathrm{p}<0.01,{ }^{* *} \mathrm{p}<0.05,{ }^{*} \mathrm{p}<0.1$ 
The result for the product differentiation variable was found to be contrary to Hypothesis $3\left(B_{2}=-0.511, p=0.029\right)$. The original logic of the hypothesis was that the firm with more differentiated products will use more diverse and stable modes, which are combined modes to recoup the development cost and protect its competitive position. The opposing empirical result is difficult to explain, but it may be that for differentiated product, a single mode is easier to manage or that even mode combination may not be necessary because of its superior nature.

Hypothesis 4 was not supported. This result indicates that mode combination is not used more frequently in particular by firms faced with investment risk as a way to minimize it in the foreign operation. This may be because the expected investment risk can be sufficiently dealt with by any type of entry modes.

There is support for Hypothesis $5\left(B_{5}=+0.479\right.$, $p=0.046$ ), confirming that mode combination can alleviate the risk of knowledge misappropriation caused by controlling partners' contractual misbehavior and protecting the firm's knowledge in the local market.

Lastly, Hypothesis 6 was weakly supported at the $10 \%$ level of significance $\left(B_{6}=-0.613, p=\right.$ $0.058)$. This result shows that albeit not strongly, the control cost in absolute terms has an effect on the mode choice of combined modes, an issue hardly explored in the extant TCT studies.

In sum, the hypotheses regarding firm size, perceived contractual risk, and expected control cost have been strongly or weakly supported by data while those regarding international involvement, product differentiation and perceived investment risk have not been supported. Particularly the variable of product differentiation turned out to be the opposite of the proposed direction.

\section{CONCLUSION}

The choice of modes for foreign market entry has been one of the most studied issues in international business (Canabal \& White, 2008; Schellenberg, et al., 2018), focused mainly on the topic of the choice among discrete individual modes, i.e., exporting, licensing, JVs and WOSs, etc. In practice, however, mode combination whereby multiple single modes are simultaneously used like a package, are very frequently observed, but theoretical and empirical research on this topic has not been much highlighted (Benito, et al., 2011).

In this paper, we examined the factors affecting the choice between a single and a combined entry mode for entry into a foreign market. Through literature review, we selected the following six variables deemed to affect firms' mode choice and established hypotheses: Firm size, international involvement, product differentiation, perceived investment risk, perceived contractual risk and the amount of the expected control cost. Then using primary empirical data on Korean manufacturing firms in Uzbekistan, an emerging market in Central Asia, we tested the proposed hypotheses.

The test results strongly show that firms with larger size and those faced with higher perceived risk prefer a combined mode and to a lesser degree, firms expecting a higher amount of the control cost prefer a single mode. Firms with more differentiated products were found to prefer a single mode, contrary to the hypothesis. Firm international involvement and perceived investment risk have no effect on the choice.

This study is not without limitations. The concept and definition of a combined mode are rough because mode combination was considered only in terms of the number of the different single modes used. Also, a generalization problem may be raised in that only a narrow range of factors extracted from the existing literature were used for theory development and empirical test and in that the data for the test was limited to a specific home country and host country. From this perspective, further research needs to fully capture the complexity and subtlety of various forms of combined modes, and to develop more rigorous and refined concepts and measures of mode combination. Also, larger and more diverse data reflecting various industry and country settings will contribute to research generalizability. In addition, the performance implications of combined mode choice and the comparison of the performance between a single mode and a combined mode can be a meaningful research area.

Despite these limitations, it is our hope that the theory and results of the present study will 
contribute both to better understanding of what firms are actually doing in practice for foreign entry mode choice and to advancement of combined entry mode research in academia. Since the extant literature focused on single mode choice, in particular, this study can play a role in sparking more firm-level empirical studies on the determinants of the choice of combined modes.

The results of this study are likely to be useful to IB managers of foreign and local firms as a tool for negotiating and choosing appropriate entry modes. Also, it is our hope that this study will contribute to policy making: Governmental officials may utilize the results of this study to attract more foreign firms into their country by better understanding firm-level strategic behavior on entry mode combinations.

\section{ACKNOWLEDGEMENT}

This paper was supported by the 2020 research fund of Hankuk University of Foreign Studies.

The author is grateful to Larisa Shin, a graduate of Hankuk University of Foreign Studies Graduate School, who conducted data collection and statistical analysis.

\section{REFERENCES}

Agarwal, S. \& Ramaswami, S. N. (1992). Choice of foreign market entry mode: Impact of ownership, location and internalization factors. Journal of International Business Studies, 23(1), 1-27.

Ahsan, M. \& Musteen, M. (2011). Multinational enterprises' entry mode strategies and uncertainty: A review and extension. International Journal of Management Reviews, 13(4), 376-392.

Allison, P. D. (1999). Multiple Regression: A Primer: Thousand Oaks, CA, USA: Pine Forge Press.

Anderson, E. \& Gatignon, H. (1986). Modes of foreign entry: A transaction cost analysis and proposition. Journal of International Business Studies, 173), 1-26.

Ang, S. H., Benischke, \& Doh, J. P. (2015), The interactions of institutions on foreign market entry mode. Strategic Management Journal, 36(10), 1535-1553.
Barney, J. (1991). Firm resources and sustainable competitive advantage. Journal of Management, 171), 99-120.

Benito, G. R. G., Petersen, B. \& Welch, L. S. (2011). Mode combinations and international operations: Theoretical issues and an empirical investigation. Management International Review, 51(6), 803-820.

Benito, G. R. G., Petersen, B. \& Welch, L. S. (2009). Towards more realistic conceptualizations of foreign operation modes. Journal of International Business Studies, 40(9), 1455-1470.

Benito, G. R. G. \& Welch, L. C. (1994). Foreign market servicing: Beyond choice of entry mode. Journal of International Marketing, 2(2), 7-27.

Brouthers, K. D. (2002). Institutional, cultural and transaction cost influences on entry mode choice and performance. Journal of International Business Studies, 33(2), 203221.

Bruneel, J. \& De Cock, R. (2016). Entry mode research and SMEs: A review and future research agenda. Journal of Small Business Management, 54(S1), 135-167.

Buckley, P. J. (1988). The limits of explanation: Testing the internalization theory of the multinational enterprise. Journal of International Business Studies, 19(2), 181193.

Canabal, A. \& White III, G. O. (2008). Entry mode research: Past and future. International Business Review, 173), 267-284.

Caves, R. E. \& Mehra, S. K. (1986). Entry of Foreign Multinationals into the US Manufacturing Industries. Boston, MA, USA: Harvard Business School Press.

Coase, R. H. (1937). The nature of the firm. Economica, 4(16), 386-405.

Contractor, F. J. (1984). Strategies for structuring joint ventures: A negotiations planning paradigm. Columbia Journal of World Business, 19(2), 30-39.

Contractor, F. J. (2001). Foreign market entry strategies. In R. L. Tung (Ed). The IEBM Handbook of International Business, 141163. London, UK: Thomson Learning.

Contractor, F. J. \& Ra, W. (2000). Negotiating 
alliance contracts: Strategy and behavioral effects of alternative compensation alternatives. International Business Review, 9(3), 271-299.

Geringer. J. M., Beamish, P. W. \& daCosta, R. C. (1989). Diversification strategy and internationalization: Implications for MNE performance. Strategic Management Journal, 10(2), 109-19.

Hashai, N., Asmussen, C. G., Benito, G. R. G. \& Petersen, B. (2010). Technological knowledge intensity and entry mode diversity. Management International Review, 50(6), 659-681.

Hennart, J. F. (1989). Transaction costs theory of equity joint ventures. Strategic Management Journal, 9(4), 361-374.

Hennart, J. F. \& Slagen, A. H. (2015). Yes, we need more entry mode studies! A commentary on Shaver. Journal of International Business Studies, 46(1), 114122.

Herrmann, P. \& Datta, D. K. (2006). CEO experiences: Effects on the choice of FDI entry modes. Journal of Management Studies, 43(4), 755-778.

Hill, C. W. L., Hwang, P. \& Kim, W. C. (1990). An eclectic theory of the choice of international entry mode. Strategic Management Journal, 11(2), 117-128.

Hymer, S. (1960). The International Operations of National Firms: A Study of Direct Foreign Investment. Cambridge, MA, USA: MIT Press (published in 1976).

Johanson, J. \& Vahlne, J. E. (1977). The internationalization process of the firm - a model of knowledge development and increasing foreign market commitments. Journal of International Business Studies, 8(1), 23-32.

Kogut, B. \& Singh, H. (1998). The effect of national culture on the choice of entry mode. Journal of International Business Studies, 19(3), 411-432.

Kostova, T. \& Zaheer, S. (1999). Organizational legitimacy under conditions of complexity: The case of the multinational enterprise. The Academy of Management Review, 24(1), 6481.
Lall, S. (1980), Monopolistic advantages and foreign involvement by U.S. manufacturing industry. Oxford Economic Papers, 32(1), 102-122.

Laufs, K. \& Schwens, C. (2014). Foreign market entry mode choice of small and mediumsized enterprises: A systematic review and future research agenda. International Business Review, 23(6), 109-1126.

Pan, Y. \& Tse, D. K. (2000). The hierarchical model of market entry modes. Journal of International Business Studies, 31(4), 535554.

Pehrsson, A. (2008), Strategy antecedents of modes of entry into foreign markets. Journal of Business Research, 61(2), 132-140.

Petersen, B. \& Welch, L. S. (2002). Foreign operation mode combinations and internationalization. Journal of Business Research, 5(2), 157-162.

Porter, M. E. (1985). Competitive Advantage. New York, NY, USA: The Free Press.

Root, F. R. (1987). Entry Strategies for International Markets. Lexington, MA, USA: Lexington Books.

Schellenberg, M., Harker, M. J. \& Jafari, A. (2018). International entry mode - a systematic literature review. Journal of Strategic Marketing, 26(7), 601-627.

Shen, Z., Puig, F. \& Paul, J. (2017). Foreign Market entry mode research: A review and research agenda. International Trade Journal, 31(5), 429-456.

Surdu, I., Mellahi, K. \& Glaister, K. (2018). Emerging market multinationals' international equity-based entry mode strategies: Review of theoretical foundations and future directions. International Marketing Review, 35(2): 342359.

Teece, D. J. (1986). Profiting from technological innovation: Implications for integration collaboration, licensing and public policy. Research Policy, 15(6), 285-305.

UzReport(1999-2015). Uzbekistan News. http://uzreport.uz/?lan=e

Williamson, O. E. (1979). Transaction-cost economics: The governance of contractual relations. Journal of Law and Economics, 
22(2), 233-261.

Wulff, J. D. (2016). A systematic assessment of empirical research on foreign entry mode. European Journal of Management, 50 5-6), 942-972.

Yan, A. \& Gray, B. (1994). Bargaining power, management control, and performance in United States-China joint ventures: A comparative case study. The Academy of Management Journal, 376), 1478-1517.

\section{ABOUT THE AUTHOR}

Wonchan Ra, email: wonra@hufs.ac.kr

Dr. Wonchan Ra is a professor of international business at the Department of International Business of Graduate School and the Division of Global Business \& Technology of Hankuk University of Foreign Studies in Korea. He earned his Ph.D. degree from Rutgers University School of Management in N.J., U.S.A. His current research interests include international strategic alliances, foreign direct investment and divestment, foreign operation modes, and cross-border knowledge transfer between firms. 